\title{
Motives Behind the Transfer of a Bank From Conventional Banking to Islamic Banking in Pakistan
}

\author{
MUHAMMAD ASIF \\ Assistant Professor, Management Sciences Department \\ City University of Science and I.T, Peshawar \\ UMAIR AHMED \\ Lecturer, Management Sciences Department \\ Qurtuba University, Peshawar \\ MUHAMMAD ZAHID \\ Assistant Professor, Management Sciences Department \\ City University of Science and I.T, Peshawar \\ AMIR KHAN \\ Lecturer, Management Sciences Department \\ Qurtuba University, Peshawar
}

\begin{abstract}
The increasing awareness on Islamic banking and finance has created a huge demand for Shari'a based or Shari'a compliant products. Banks, especially are trying to capture this huge market by either converting themselves into a full fledge Islamic banks or opening a window for the Islamic based transactions. This study highlights the reasons why traditional banks turned towards Islamic model. The phenomenon of traditional banks turning into Islamic form was reinforced by the success of these banks averting the recent world economic crises. For data collection 80 respondents were selected, a proxy of five variables were undertaken as measurement. Variables of the study were:Transfer to Islamic Banking(TIB) was taken as dependent variable whileShari'a compliance(SC), Risk and Return(RR), Customer need(CN) and Performance of Islamic banks(PI) were taken as independent variables for which adopted questionnairewas used for data collection. The result of this research is that the banks are transferring from conventional banking to Islamic banking is just because of Shari'a Compliance, performance of Islamic banks and customer need for Islamic product.
\end{abstract}

Key words: Transfer of Banks, Shari'a Compliance, Performance of Islamic banks, customer needs.

\section{Introduction}

Like conventional bank, Islamic bank is an intermediate and representative of money of other people but the difference is that it shares profit and loss with its investors only on the permitted bases of Islamic Shari'a. This difference presents the element of reciprocal in Islamic banking, makes the investors as customers with some proprietorship of right in it (Dar and Presley 2000). Islamic banking and conventional banking varies in that while the conventional banking follows conventional interest-based principle, the Islamic banking is based on interest-free principle and principle of Profit-and-Loss (PLS) sharing in accomplishment their businesses as intermediaries (Arif 1988). 
According to Shehzad (2008) Islamic Bank is a financial system whose key aim is to fulfill the teachings of the Holy Quran. Islamic law reflects the commands of God and this regulates all the various aspects of a Muslim's life and hence Islamic finance is directly involved with spiritual values and social justice. The theory of Islamic banking is based on the concept that interest is strictly forbidden in Islam, and that Islamic teachings provide the required guidance on which to base the working of banks. The basic principle that has guided all theoretical work on Islamic banking is that although interest is forbidden in Islam, trade and profit is encouraged (Dusuki, Dusuki, \& Abdullah, 2007). Pakistan was founded and made for implementing Islamic rules and laws in an independent country. All religious circles and groups were constantly demanding for elimination of Riba from the financial and banking system of Pakistan as the constitutions of the country had already included the elimination of riba as early as possible because the laying foundation of Pakistan is to follow the rules and laws as mentioned in Quran and Sunnah. As a result Islamic Banking was introduced in 1980 in Pakistan and it became role model for all Muslim countries (Asif, \& Anjum, 2012). Eventually many private Islamic banks emerged as well as conventional banks also started facilitating Islamic Products such as Musharika, Mudariba, Murabaha and Ijara etc. and many other schemes for Depositors and borrowers (Rajeh, Alamer, Salamon, Qureshi, \& Rasli, 2015).

Presently all Conventional and Private Banks are providing services of Islamic Banking but currently there are only three large private banks which are purely operating as per Islamic rules under the supervision and guidelines of Shariah Board established by famous Muftees of a leading Islamic Institution. As per Shariah requirements, the funds and products of Islamic Banking are being managed separately from the conventional banks. It is experienced that the business of those businessmen expanded who did the borrowing according to Islamic laws and got rid of riba from their activities.

The Islamic Economy System is based on the following principles

1. All wealth belongs to Almighty Allah and Man is the trusty of Wealth.

2. Wealth must be in circulation and holding of wealth is restricted.

Conventional economy creates phenomena of distribution wealth un justly as it is originated by man-made laws and system. Islamic economy eliminates the monopoly of an Individual, Group or Organization to keep control on World monitory policies and avail most of the resources by blocking wealth. It also protects the society and secures the needs of the people. Basic principle of Islam Banking is to prohibit in riba based financing, lending and in sales. Interest is restricted and the owner of funds becomes Investor instead of Creditor. The Investor and Entrepreneur share the business on risk, profit and loss according to the ratio of investment and participation according to their Capital and Skill/Performance.

Conventional banks focus on business customers. Businesses need checking and savings accounts just like individuals do. But they also need more complex services, and the dollar amounts (or the number of transactions) can be much larger.

Banks play a very useful and crucial role in the economic life of every nation. They have control over a large part of the supply of money in circulation, and they can influence the nature and character of production in any country. In order to study the economic significance of banks, we have to review the general and important functions of banks: Removing the deficiency of capital formation; Provision of finance and credit; Extension of the size of the market; Act as an engine of balanced regional development; Financing agriculture and allied activities; For improving the standard of living of the 
people.

\subsection{Problem Statement}

Now a day's Islamic banks have achieved great fame throughout the world and a lot of banks are switching towards Islamic banking which is obvious from the increase in number of branch network in Pakistan. So there is a need to identify those main motives which are the main cause of switching from conventional to Islamic banking system.

\subsection{Objective of research}

The main objective of this research is to determine the motives underlying the transfer of conventional bank to Islamic bank. The research objectives are:

- To investigate the effect of Shariah compliances on transfer to Islamic bank.

- To evaluate the effect of Risk and Return on transfer to Islamic bank.

- To found the effect of Customer needs for Islamic Products on transfer to Islamic bank.

- To measure the effect of Performance of Islamic banking on transfer to Islamic bank.

\subsection{Research Questions}

The main question underlying this research is that, what are the motives behind the transfer of conventional bank to Islamic bank.

Questions considering this research are as under

1. What is the effect of shariah compliances on transfer to Islamic bank?

2. What is the effect of Risk and Return on transfer to Islamic bank?

3. What is the effect of Customer needs for Islamic Products on transfer to Islamic bank?

4. What is the effect of Performance of Islamic banking on transfer to Islamic bank?

\subsection{Significance of the study}

The significance of this study is to develop the Islamic banking system in Pakistan, to promote more Islamic banking deposits and investments encourage more investors

and capture conventional banking market share, eliminate Riba based financing, and provide with true and fair banking system based on Islamic jurisprudence.From the past decade researches related to Islamic financing are increasing in number as it reaches more scope in our society. More specifically the phenomenon of the Conversion Process from Conventional Banks into Islamic Banking has gained many researchers attention and had made their findings to this study, indicating factors that impacts the process of conversion, for instance; law imposed, risk and profit rates, customer needs for Islamic products etc.., many of which are explained by studies conducted by researchers.

According to Shafi and Shahimi (2016) in their research have identified that the human resources, regulations and legislation, sharia's compliance, conversion resistance, and Islamic banking products are the major factors that affect the process of conversion from the conventional-based banking to Islamic banking. Accordingly, their study purported a theoretical framework to examine the above prominent factors in light of the conversion process from conventional-based banking to an Islamic one,

Similarly Ali, Ali and Khwaja (2013) have also reviewed that there is a lack of proficiency in Islamic Banking system. That do not have a patronizing level of specialist team that may convince customers to make Islamic Banking as their first and last option. Moreover, another obstacle in this observation was the shortage of realization among the people concerning the Islamic Banking.In a related study, Ghafoor (2009), focused on the 
comparison of the performance of newly established six Islamic Commercial Banks with the performance of the similar size of the selected Conventional Commercial Banks in order to draw the conclusion whether these new Islamic Commercial banks can operate in a competitive environment and meet the expectations of their depositors, besides sustaining their growth. Moreover, Omar (2016) have also Isolated both negative and positive results of leading towards the Islamic banking as an effective tool of providing financial products based on the Islamic Sharia rulings against that of conventional commercial banking, he resolved to recruit specialists in the Islamic jurisprudence and Islamic banking to define the legitimacy of conventional banking works to the decision makers, aiming at eliminating their mental postponements and vagueness of practicing the conventional financial works.

In a research related to the study of problems and issues in transformation from conventional banking to Islamic banking by Rafay and Ramla (2015) in which they concluded that the prominence of Islamic finance remains not only within Islamic communities, but internationally due to a rising awareness of the problems predominant in conventional banking and a growing interest in Islamic finance. Leading IFIs spread their networks across all continents and create far reaching impacts in world economies. Zohaib (2009) in his research concluded that the success of the present re inauguration of Islamic Banking in Pakistan by the State Bank of Pakistan has been a result of careful planning and hard work. The results has proven that the strategy for introduction of Islamic banking in Pakistan has worked well. The growth has been striking by any standards. Achieving a market share of $4.5 \%$ in about 5 years in a rapidly growing banking sector is a remarkable accomplishment compared to the best in class countries. The re-launch experience has been irreplaceable and serves as a strong base on which the strategy has been put in place.

Rafay and Sadiq (2015) in a related study to this effect found that Islamic finance is neither religion based nor for a specific community. Since mid 20thcentury Islamic finance is experiencing a revival because of the struggle of the Muslims to regain independence from colonial masters and that now has been spread in every nook and corner of world with zeal and zest. It has gone beyond the boundaries of Islamic world to almost all global financial markets. The importance of Islamic finance remains not only within Islamic communities, but internationally due to a rising awareness of the problems prevalent in conventional banking and a growing interest in Islamic finance. Leading IFIs spread their networks across all continents and create far reaching impacts in world economies. Similarly a group of researchers Michel, Baddar \& Beal (2015) in Malaysian context also had their findings to this event their evident was that; from the perspectives of a number of senior Malaysian Islamic banking officials was presented according to three major themes that were identified in their data trial, including the quality of service and factors affecting choice of bank products, issues related to Malaysia as the context, and finally, issues related to offering Islamic products and the extent to which Shariah compliance being adhered to. This latter theme raises the ongoing issue as to whether (and to what extent do) Islamic banking practices reflect these broader ethical and moral considerations dictated by Shariah principles.

Bilal and Abbas (2015) in their group study about Comparison of Islamic banking and conventional banking, two main approaches have been followed; 1st Stochastic Frontier Approach (SFA) and traditional financial ratios. Frontier Approach as compared to traditional financial ratios was considered superior because in Frontier Approach statistical techniques or programming was used and also it removed input and 
output price differences and factors that affect the performance of a firm. Conclusively, higher Rate of return has been seen for Islamic banks as compared to Conventional banks and customers with Islamic background prefer Islamic banking system as Islamic banks are based on Islamic Sharia principles. According to Azhar (2010) has also made a contribution to this study by investigating the satisfactory level of the customers of Islamic banks and conventional banks in Pakistan it is found that economic benefits, financial position of banks, latest facilities, and interest on deposits, strong global image and reputation are the factors that are motivating customers towards conventional banks. Interest free loan, financial position of bank, Islamic teaching and Shariah, knowledge of Islam and religious environment are the factors that are motivating customers towards Islamic Banks. The conclusion of this study showed that the customers of both the banks either they were from islamic banks or conventional banks were satisfied with the facilities provided by the banks but the customers of conventional banks were more satisfied than the customers of Islamic bank. Hanif (2011) in his comparative attempted to address the perceptional issues by identifying the similarities and differences in Islamic and conventional banking. Indications from this study suggested that Islamic banking is very much practiced like modern conventional banking with certain limitations imposed by Shari'a and addresses the large number of business requirements successfully hence observing Islamic banking as totally foreign to business world is not correct. It is further found in the study that Islamic banking is not a mere copy of conventional practices rather major differences exist in the operations of Islamic Financial Institutions (IFIs) in comparison with conventional banking. IFIs have succeeded in creating belief in the eyes of investors and receive deposits on profit and loss sharing basis nevertheless investment and financing options available to Islamic banks are restricted in comparison of conventional banks (Asif, 1980).

\subsection{Variables}

\subsubsection{Dependent variables}

\subsubsection{Transfer of Islamic banking}

It means that the banks are transferring from conventional banking to Islamic banking.

\subsubsection{Independent Variables}

\subsubsection{Shari'a Compliance}

Shari'a compliance funds are an investment fund which meets all the requirements of Shari'a law and the principles articulated for "Islamic finance"

\subsubsection{Risk and Return}

Risk implies future uncertainty about deviation from expected earnings or expected outcome. Risk measure the uncertainty that an investor is willing to take to realize a gain from an investment. Return is the gain or loss of a security in a particular period. The return consists of the income and capital gains relative on an investment, and it is usually quoted as percentage. Higher risk is associated with greater probability of higher return and lower risk with a greater probability of smaller return.

\subsubsection{Customer Needs for Islamic Products}

Consumer may require a loan though he must pay interest which is firstly prohibited in Islam therefore there is no probation for that, secondly a loan from conventional bank requires monthly payment of interest that grows exponentially if not paid with in that period, for this reason Islamic banks

provides an interest free loan with no extra payments, that is why we say that Islamic bank is an efficient tool to satisfy consumer needs. 


\subsubsection{Performance of Islamic Banks}

Since Islamic bank performance was suggestively good as compared to conventional banks, because of the products provided by Islamic banks were more profitable on the basis of performance comparison between Islamic and conventional banks elaborated in this study, furthermore the Islamic banking system provides a more stable and fair financing facilities therefore series of banks converted into Islamic banks.

\section{Methodology}

This research is a quantitative in nature. Data was collected through adopted questionnaire. Simple random sampling technique was used to collected the data.80 questionnaires were distributed out of which only 63 were useable for analysis.

The data is analyzed through SPSS software using regression analysis.

\subsection{Research Design}

It was a cross-sectional research and collects primary data by using Closed-ended questions are those which can be answered by a simple "yes" or "no," while open-ended questions are those which require more thought and more than a simple one-word answer. The analysis used in this study is based on closed-ended Questionnaire for this reason a questionnaire consisting of a set of interrelated question was designed for evaluating the motives behind the transfer of banks from conventional to Islamic banks.

\subsection{Research Model:}

To discover the reasons for the transfer of conventional banks to Islamic banks the following model is used for signifying this connection:

$$
\mathrm{TIB}=\hat{\mathrm{a}} 0+\mathrm{a} 1 \mathrm{SC}+\hat{\mathrm{a}} 2 \mathrm{RR}+\hat{\mathrm{a}} 3 \mathrm{CNI}+\hat{\mathrm{a}} 4 \mathrm{PI}+\mu
$$

Where TIB represents "Transfer to Islamic Banking" that is the dependent variable, $\hat{a} 0$ is the magnitude or constant variable which shows a constant effect that remain fixed, SC represents the Shariah Compliance, RR represent Risk and return, CNI represent customer need for Islamic products, PI represent performance of Islamic Banks all of which are independent variables.

\subsection{Population of the Study}

The population of the study is consisting of 138 employees working at those conventional banks which are dealing with Islamic products in the shape of Islamic banking window or a separate branch.

\subsection{Sample Size}

80 respondents were selected interviewed though only 63 employees were able to response thus the response rate is calculated a $63 / 80 * 100$ which equals $78.7 \%$ responses on the average. Islamic Banks that are included into this study are

Table 1: Sample Size of Banks

\begin{tabular}{lll}
\hline \hline 1 & Allied Bank & 7 \\
2 & Askari Bank & 7 \\
3 & Bank Al-Habib & 6 \\
4 & Bank Al-falah & 4 \\
5 & Faysal Bank & 8 \\
6 & Habib Bank & 11 \\
7 & MCB Bank & 8 \\
8 & Silk Bank & 3 \\
9 & United Bank & 9 \\
\hline \hline
\end{tabular}

\subsection{Data Collection Method}


The data was collected through 5 points Likert scale Questionnaire. Questionnaire were distributed among the conventional banks employees during working hrs as it was convenient time to collect the data.

\section{Reliability Test}

Table 2: Results of reliability test

\begin{tabular}{ll}
\hline \hline Construct & Cronbach's Alpha \\
\hline \hline Transfer Islamic Bank (TIB) & 0.704 \\
Shariah Compliance (SC) & 0.720 \\
Risk \& Return (RR) & 0.883 \\
Customer Need for Islamic Products (CNI) & 0.721 \\
\hline \hline
\end{tabular}

According to Uma Sekaran (2003), the closer the reliability coefficient Cronbach's Alpha gets to 1.0 , the better will be the reliability. In general, reliability less than 0.60 is considered to be poor, 0.70 acceptable and over 0.80 and 0.90 are considered good and very good respectively. The reliability tests of our constructs happened to be in the acceptable range.Now we did factor analysis of all these questions which are TIB, SC, RR, CNI, PI and there is error/mistake in some questions. When we did factor analysis of TIB question, there is also some problem in TIB4 questions but when we skip TIB4 from question \# 1 because it show less than the standard value. Than the result come according to the standard value which is 0.70 or greater. After that we also same process with RR3 in question \# 3. Because they also show the error in the result. After the eliminating of RR3 from question \# 3 then the result come according to the standard value which 0.70 or greater. Since the average range is above 0.70 or greater it can be suggested that the construct is of an acceptable form and in acceptable range.

Table 3: Descriptive Statistics

\begin{tabular}{|c|c|c|c|c|c|}
\hline & $\mathrm{N}$ & Minimum & Maximum & Mean & Std. Deviation \\
\hline TIB & 63 & 1.67 & 4.67 & 3.5741 & .63060 \\
\hline SC & 63 & 1.50 & 5.00 & 3.6587 & .83919 \\
\hline $\mathrm{RR}$ & 63 & 1.00 & 5.00 & 3.1323 & .77723 \\
\hline $\mathrm{CNI}$ & 63 & 1.00 & 4.50 & 3.4074 & .61840 \\
\hline PI & $\begin{array}{l}63 \\
63\end{array}$ & 1.00 & 5.00 & 3.4603 & .78572 \\
\hline
\end{tabular}

Valid N (listwise)

In the above table it is observed that the number of observations are 63. The minimum value of TIB is 1.67 and the maximum value is 4.67, its mean is 3.57 and it is deviating from its mean by 0.63 . The minimum value of SC is 1.50 and the maximum value is 5.00 , its mean is 3.65 and it is deviating from its mean by 0.83 . The minimum value of $R R$ is 1.00 and the maximum value is 5.00 , its mean is 3.13 and it is deviating from its mean by 0.77 . The minimum value of CNI is 1.00 and the maximum value is 4.50 , its mean is 3.40 and it is deviating from its mean by 0.61 . The minimum value of PI is 1.00 and the maximum value is 5.00 , its mean is 3.46 and it is deviating from its mean by 0.78 . 
Table 4: Model Summary

\begin{tabular}{lllll}
\hline \hline Model & $R$ & R Square & $\begin{array}{l}\text { Adjusted R } \\
\text { Square }\end{array}$ & $\begin{array}{l}\text { Std. Error of the } \\
\text { Estimate }\end{array}$ \\
\hline \hline 1 & $.651^{\mathrm{a}}$ & .424 & .384 & .49475 \\
\hline \hline
\end{tabular}

a. Predictors: (Constant), PI, RR, SC, CNI

ANOVAa

\begin{tabular}{|c|c|c|c|c|c|c|c|}
\hline Model & & $\begin{array}{l}\text { Sum } \\
\text { Squares }\end{array}$ & Df & & Mean Square & $\mathrm{F}$ & Sig. \\
\hline \multirow{3}{*}{1} & Regression & 10.457 & & & 2.614 & 10.680 & $.000^{\mathrm{b}}$ \\
\hline & Residual & 14.197 & & 58 & .245 & & \\
\hline & Total & 24.654 & & 62 & & & \\
\hline
\end{tabular}

a. Dependent Variable: TIB

b. Predictors: (Constant), PI, RR, SC, CNI

Coefficients $^{\mathrm{a}}$

\begin{tabular}{|c|c|c|c|c|c|c|}
\hline \multicolumn{2}{|c|}{ Model } & \multicolumn{2}{|c|}{$\begin{array}{l}\text { Unstandardized } \\
\text { Coefficients }\end{array}$} & \multirow{2}{*}{$\begin{array}{l}\text { Standardized } \\
\text { Coefficients }\end{array}$} & \multirow[t]{2}{*}{$\mathrm{t}$} & \multirow[t]{2}{*}{ Sig. } \\
\hline \multirow{6}{*}{1} & & B & Std. Error & & & \\
\hline & (Constant) & 1.326 & .404 & & 3.281 & .002 \\
\hline & $\mathrm{SC}$ & .164 & .088 & .219 & 3.864 & .000 \\
\hline & $\mathrm{RR}$ & -.046 & .096 & -.056 & -.476 & .636 \\
\hline & $\mathrm{CNI}$ & .288 & .184 & .282 & 2.567 & .023 \\
\hline & PI & .233 & .121 & .291 & 1.936 & .008 \\
\hline
\end{tabular}

a. Dependent Variable: TIB

Reporting results in regular econometrics-format

$\mathrm{TIB}=1.326+0.164 \mathrm{SC}-0.046 \mathrm{RR}+0.288 \mathrm{CNI}+0.233 \mathrm{PI}+.40 \mu$
(30281)
(3.864)
$(-0.476)$
(20567)
(1.936)
(t-stats)
$(0.002)$
$(0.000)$
$(0.636)$
$(0.023)$
(0.008)
(p-values)

$\mathrm{R}=0.651 \quad \mathrm{R}^{2}=0.424 \quad \mathrm{R}$ adjusted $=0.384$

$\mathrm{F}=10.680(\mathrm{p}$-value $=0.000) \quad \mathrm{N}=63$

\section{Evaluation of empirical results (in terms of $t, F \& \mathbf{R}^{2}$ )}

- The above model as a whole is statistically significant at $\mathrm{F}=10.680$ at á < 0.01 ; however only $\left(\mathrm{R}^{2}\right) 42.4$ percent variation in dependent variable has been explained by variations in explanatory variables included.

- As far as individual explanatory variables are concerned, Shariah Compliance (SC) and performance of Islamic bank (PI) is statistically significant at á $<0.01$, while, Customer needs for Islamic product $(\mathrm{CNI})$ at á $<0.05$, however,

risk and return (RR) has turned out statistically insignificant because its $\mathrm{p}$ value 
is greater than 0.05 .

The three elements of Shariah Compliance, Performance of Islamic banks and Customer needs for Islamic products contribute statistically significantly and positively towards Transfer of Islamic banks, compared to Risk and Return which appears statistically insignificant. The Sharia compliance, customer need for Islamic products and performance of Islamic banks contribute positively towards transfer to Islamic bank.

\section{Conclusion}

The purpose of this research is to find out the reason that why the banks are transfer from conventional bank to Islamic banking. Four challenges were proposed to influencesuch a conversion namely, SC, RR, CNI and PI to conversion, and Islamic banking products, upon which four hypotheses were developed The objective of this research isto determine the motives underlying the transfer of conventional bank to Islamic bank Study have select 48 those bank which are converted from conventional banks to Islamic banking which the data was collected are currently functional, and operating from which 193 employees were interviewed though only 63 employees were able to response thus the response rate is calculated a $63 / 80 * 100$ which equals $78.7 \%$ responses on the average. The model of this study as a whole is statistically significant at $\mathrm{F}=10.680$ at á $<0.01$; however only $\left(\mathrm{R}^{2}\right) 42.4$ percent variation in dependent variable has been explained by variations in explanatory variables included.As far as individual explanatory variables are concerned, Shariah Compliance (SC) and performance of Islamic bank (PI) is statistically significant at á $<0.01$, while, Customer needs for Islamic product $(\mathrm{CNI})$ at á $<0.05$, however, risk and return (RR) has turned out statistically insignificant because its $p$ value is greater than 0.05. The result of this research is that the banks transfer from conventional bank to Islamic bank is because of Shariah Compliance, performance of Islamic banks and customer need for Islamic product.

\section{References}

Ababneh, A. (2016). Heritage Management and Interpretation: Challenges to Heritage Site-Based Values, Reflections from the Heritage Site of Umm Qais, Jordan. Archaeologies, 12(1), 38-72.

Alani, F. S., \& Yaacob, H. (2012). Traditional banks conversion motivation into islamic banks: evidence from the middle east. International BusinessResearch, 5(12), 83.

Ali, F., Raziq, H., Aleem, A., Latif, S., Arslan, M., \& Muhammad, A. S. (2011). Customer satisfaction and islamic banking in Pakistan. International Journalof Asian Social Science, 1(4), 89-96.

Ali, L., Ali, A., \& Khwaja, H. (2013). Comparison of Islamic and Conventional Banking on the Basis of Riba and Services: A case study of Peshawar Region. International review of management and business research, 2(3), 837.

Asif, M., \& Anjum, M. A. (2012). Acceptance of Islamic Banking in Muslim Customers. International Review of Management and Business Research, 1(2001), 9-17.

Asif, M. F. A. S. M. A. A. (1980). Factors Determining the Attitude of Customers towards Islamic Banking: A Study of Peshawar, Pakistan. Journal, Abasyn Sciences, Social, 211-219.

Awan, A. G. (2009). Comparison of Islamic and conventional banking in Pakistan. Proceedings 2nd CBRC, Lahore, Pakistan, 1-36.

Bilal, M., \& Abbas, S. (2015). Comparison of Islamic banking and conventional banking: An empirical review. Studies, 4(1).

Hanif, M. (2014). Differences and Similarities in Islamic and Conventional Banking. 
Hanif, M., Tariq, M., \& Tahir, A. (2011). Comparative Performance Study of Conventional and Islamic Banking in Pakistan.

Khan, F. (2010). How 'Islamic'is Islamic banking? Journal of Economic Behavior \&Organization, 76(3), 805-820.

Moin, M. S. (2008). Performance of Islamic banking and conventional banking inPakistan: A Comparative Study.

Rafay, A., \& Sadiq, R. (2015). Problems and issues in transformation from conventional banking to Islamic banking: Literature review for the need of a comprehensive framework for a smooth change.

Rod, M., A. L. Hussan, F. B., \& Beal, T. (2015). Conventional and Islamic banking: perspectives from Malaysian Islamic bank managers. International Journal of Islamic Marketing and Branding, 1(1), 36-54.

Shafii, Z., Shahimi, S., \& Saaid, A. (2016). The Factors that Influence the Conversion Process from Conventional Banks into Islamic Banking in Libyan

Conventional Banks: Proposing Conceptual Framework. International Journal of Academic Research in Management and Business, 1(2), 77-87.

Sheikh, M., Taseen, U., Haider, S., \& Naeem, M. (2010). Islamic Vs Conventional Banks in Pakistan (A case study of Bahawalpur). Journal of Education Research.

Sole, J. A. (2007). Introducing Islamic Banks into Coventional Banking Systems.

Rajeh, A., Alamer, A., Salamon, H. Bin, Qureshi, M. I., \& Rasli, A. M. (2015). How do We Measure Corporate Social Responsibility of Islamic Banks through their Business Processes and Oriented Outcomes? International Journal of Economics and Financial Issues, 5((Special Issue), 190-197.

Dusuki,W. A., Abdullah, N. I., Dusuki, A. W., \& Abdullah, N. I. (2007). Why do Malaysian customers patronise Islamic banks? Bank Marketing, 25(3), 142-160. https://doi.org/10.1108/02652320710739850 